\title{
Knife Device
}

National Cancer Institute

\section{Source}

National Cancer Institute. Knife Device. NCI Thesaurus. Code C54021.

A cutting device usually consisting of a sharpened blade attached to a handle. 